\title{
„Proceres et primates Regni Poloniae" W związku z książką Dariusza Wróbla: Na pierwszym planie. Możni i szlachta polska wobec bezkrólewia po śmierci Ludwika Andegaweńskiego. Lublin, Wydawnictwo UMCS, 2020, ss. 586
}

1. Obszerna praca, obejmująca 502 strony tekstu (nie licząc bibliografii i indeksów), porusza jeden $\mathrm{z}$ najciekawszych okresów w dziejach państwa polskiego w późnym średniowieczu. Istniejące kilkadziesiąt lat Królestwo Polskie, powstałe z zamętu przełomu wieków XIII i XIV, musiało stawić czoła poważnemu kryzysowi, jaki nastąpił po śmierci Ludwika Węgierskiego w roku 1382. Dariusz Wróbel napisał książkę, w której postanowił kompleksowo i w wielu miejscach całkiem na nowo opisać lata bezkrólewia 1382-1384. Monografia składa się z siedmiu dużych rozdziałów, podzielonych na szereg mniejszych części, i odpowiada w przybliżeniu chronologii wydarzeń czasów bezkrólewia ${ }^{1}$. Dwa pierwsze rozdziały mają charakter obszernego wprowadzenia i opisują zdarzenia bezpośrednio poprzedzające śmierć króla Ludwika Węgierskiego. Pozostałe dotyczą okresu od zgonu tego władcy we wrześniu 1382 roku, aż do koronacji Jadwigi Andegaweńskiej w październiku roku 1384. Całość została zamknięta krótkimi Refleksjami końcowymi.

${ }^{1}$ Są to w kolejności: 1. Personalny obraz elit urzędniczych okresu bezkrólewia; 2. Sytuacja polityczna $w$ przededniu bezkrólewia; 3. Batalia o zasade rezydencji króla w Polsce; 4. Poczatki alternatywy mazowieckiej (piastowskiej); 5. Między wiernościa Andegawenom a kandydatura mazowieckiego Piasta; 6. Wojna Siemowita o korone polska 1383-1385;

7. Zabiegi o przystanie do Polski Jadwigi Andegaweńskiej. 
2. Podstawowym celem książki jest „obserwacja oraz analiza zabiegów i działań podejmowanych przez Polaków - głównie możnych, ale także mniej eksponowanych przedstawicieli wspomnianego narodu politycznego - w ramach rozgrywki z dworem w Budzie o respektowanie wcześniej zawartych uzgodnień w sprawie warunków sukcesji po Ludwiku" (s. 16). Ponadto skutkiem tak zarysowanych badań ma być pokazanie procesu usamodzielniania się elit politycznych Królestwa Polskiego oraz przyjmowania przez te elity coraz bardziej i wyraźniej ogólnopolskiego horyzontu politycznego, przełamującego partykularne, dzielnicowe interesy. Trzecim wreszcie komponentem tworzącym omawianą książkę jest śledzenie „dyskursu politycznego, w rozumieniu Autora nie tylko frazeologii tekstów, lecz również odzwierciedlone w nich postrzeganie i oceny realiów politycznych, a więc faktów, instytucji i zjawisk, wreszcie samych »autorów « tekstów i ich politycznych adwersarzy" (s. 16). Te tak ciekawie zarysowane cele badawcze nie znalazły jednak w pełni odzwierciedlenia na kartach recenzowanej publikacji.

3. Historyk skupił się przede wszystkim na próbie ustalenia zupełnie nowej faktografii i interpretacji zdarzeń, które miały miejsce w czasie bezkrólewia. Objawiło się to bardzo drobiazgowymi analizami, których cechą wspólną jest budowanie argumentacji na podstawie z góry założonej tezy. Chciałbym zilustrować to trzema przykładami: opisem okoliczności przybycia do Polski Zygmunta Luksemburskiego oraz dwoma epizodami związanymi z politycznymi aspiracjami Siemowita IV w pierwszym roku bezkrólewia.

Całość rozważań nad sprawą pojawienia się młodego Luksemburga w Polsce (s. 126-146) oparta została przez D. Wróbla na dokonanym przez niego spostrzeżeniu źródłowym, skądinąd niezwykle cennym. Przekaz Jana z Czarnkowa mówi w skrócie o tym, że po śmierci Ludwika Zygmunt Luksemburski, dowodzący oblężeniem Odolanowa (trzymanego przez Bartosza Wezenborga), natychmiast zwinął wojsko i wrócił do Poznania, rozpoczynając usilne zabiegi o potwierdzenie swoich praw do polskiego tronu ${ }^{2}$. D. Wróbel stawia tezę, że Zygmunta nie było pod Odolanowem 8 września, ponieważ 5 września 1382 roku był w Czeskich Budziejowicach, gdzie wraz z braćmi Wacławem IV i Janem Zgorzeleckim wystawił dokument dla biskupa merseburskiego i arcybiskupa magdeburskiego Fryderyka (s. 143-145)3. Autor podkreśla, że ostatnie znane wystąpienie Zygmunta w Polsce przed zgonem Ludwika pochodzi z 31 sierpnia, z miejscowości określonej przez wydawcę jako Brysk, którą to Wróbel identyfikuje jako Parsk koło Gostynia, a więc niedaleko terenów walk

2 Joannes de Czarnków, Chronicon Polonorum. Wyd. J. Szlachtowski. W: MPH, T. 2, s. $721-722$.

${ }^{3}$ Regesten der Markgraffen von Magdeburg aus dem Hause Luxemburg. Hrsg. F. Heidemann. Warendorff 2016, nr 125; Codex diplomaticus Brandenburgensis. Hrsg. E. Riedel. Bd. 3. Seria B. Berlin 1846, nr 1204. 
z Bartoszem w Koźminie 4 . Taka rekonstrukcja faktograficzna pozwoliła mu zakwestionować wiarygodność przekazu Janka z Czarnkowa i tym samym nieco inaczej interpretować znaczenie wszystkich ówczesnych zdarzeń. Identyfikowanie Bryska z Parskiem jest kuszące i niewykluczone. Ale warto jednak wspomnieć, czego autor nie czyni, że nazwa „Brysk” jest notorycznie używana w niemieckojęzycznych źródłach na oznaczenie Brześcia Kujawskiego ${ }^{5}$. Cały zaś wywód badacza oparty jest na trzech podstawowych założeniach: 1) nazwa „Brysk” jako miejsce wystawienia dokumentu Zygmunta oznacza Parsk; 2) bezdyskusyjny fakt obecności Zygmunta w Czeskich Budziejowicach 5 września; 3) możliwość dotarcia z Parska na południe Czech w ciągu 6 dni (wliczając w to 31 sierpnia oraz 5 września, czyli dni wystawienia dyplomów). Pierwsze założenie jest teoretycznie możliwe do przyjęcia, ale bardzo dyskusyjne. Druga i trzecia kwestia są poważniejsze, bo przyjęte zostały przez autora w sposób trochę milczący, jakby były to sprawy niemal oczywiste (s. 134). Tymczasem wcale tak nie jest, ponieważ droga z Parska do Czeskich Budziejowic liczyła — przy optymistycznym podejściu — ok. 470—480 kilometrów. A to przy założeniu, że trwała sześć dni, daje ponad 70 kilometrów na dobę, co jest szybkością forsowną, tym bardziej że po drodze trzeba było przekroczyć Sudety. Podnoszę ten wątek, ponieważ D. Wróbel doskonale zdaje sobie sprawę z realiów średniowiecznego podróżowania ${ }^{6}$. Jest jeszcze kwestia dokumentu z Budziejowic. Oprócz samego faktu jego wystawienia, który nie budzi wątpliwości, ważna jest jego treść, czyli porozumienie między arcybiskupem magdeburskim i biskupem merseburskim Fryderykiem z Hoymu a Wacławem IV Luksemburskim i jego braćmi. Porozumienie zostało zawarte przede wszystkim $\mathrm{w}$ interesie duchownego i Wacława IV, ponieważ obsada arcybiskupstwa magdeburskiego była zawsze elementem polityki luksemburskiej, a dzierżyciele tej godności związani byli z dworem praskim. Podobnie było z Fryderykiem z Hoymu, który w lutym 1382 roku zastąpił zmarłego Ludwika z Miśni ${ }^{7}$. Porozumienie zawarte w Budziszynie we wrześniu 1382 roku gwarantowało ze strony Luksemburgów prawa i posiadłości kościoła magdeburskiego znajdujące się w ich władztwach oraz pomoc Fryderykowi przeciw

${ }^{4}$ KDW, T. 3, nr 1802.

${ }^{5}$ Zob. np. Katalog dokumentów i listów królów polskich z Archiwum państwowego w Gdańsku (do roku 1492). Oprac. M. Grulkowski, B. Możejko, S. Szybkowski. Gdańsk 2014, nr 81 (Brisk), 82 (Bryszk), 92 (Briszk).

${ }^{6}$ D. Wróbel: Misja Sędziwoja z Szubina do Zadaru. Epizod z czasów bezkrólewia w Polsce 1382-1384. „Balcanica Posnaniensia” 2018, T. 25, s. 73: „Średnie tempo podróżowania konno mieści się w przedziale od 25 do $60 \mathrm{~km}$ dziennie. Pierwsza wartość w praktyce występowała najczęściej i oznacza umiarkowane tempo podróży, tzn. bez zbytniego pośpiechu. W razie potrzeby możliwe było przemieszczanie się ponad dwa razy szybciej. Pokonywanie większych odległości dziennie (nawet do $130 \mathrm{~km}$ ) było możliwe już tylko przy użyciu rozstawnych koni”.

${ }^{7}$ Następca Fryderyka, zmarłego już w listopadzie 1382 r., Albrecht z Kwerfurtu był od 1395 r. kanclerzem Wacława IV. 
wszystkim z wyjątkiem papieża. Arcybiskup ze swej strony wystawił rewersał zobowiązań ${ }^{8}$. Było to więc porozumienie ważne przede wszystkim dla króla czeskiego i rzymskiego Wacława, ponieważ dotyczyło spraw tak naprawdę wewnątrzniemieckich, gdzie arcybiskup występował jako władca i duchowny. Można zatem zastanowić się: czy rzeczywiście Zygmunt pędziłby z Parska do Budziejowic ponad 70 kilometrów na dobę, żeby znaleźć się wśród wystawców takiego dokumentu? Czy jego obecność była tam niezbędna? Skoro autor w tym samym fragmencie swej książki (s. 131) uważa za niekonieczną podróż Zygmunta do Polski, po złożeniu mu przez starostów hołdu wierności w Zwoleniu, to dlaczego upiera się przy pobycie margrabiego w Czeskich Budziejowicach? Wacław IV śmiało mógł wystąpić w imieniu swych braci.

Obstawanie Dariusza Wróbla przy takiej interpretacji zdarzeń zmusiło go do zasadniczej reinterpretacji całości obrazu politycznych zawirowań 2. poł. 1382 roku. W pierwszej kolejności dokonał on rewizji znaczenia zjazdu w Zwoleniu w lipcu 1382 roku. Lubelski mediewista bagatelizuje przekaz Jana z Czarnkowa, uważając, że do uznania bądź nieuznania Zygmunta za króla wystarczała wola Ludwika, i wysuwa tezę, że całe spotkanie zostało zaaranżowane tylko po to, aby postawić młodego władcę na czele polskich sił mających ostatecznie zniszczyć pozycję Bartosza Wezenborga: „Możliwe jednak, że zbyt wiele chcemy wyczytać ze sformułowania Jana z Czarnkowa o braniu w posiadanie zamków i miast Królestwa Polskiego. Może na pierwszy plan należałoby wysunąc jednak samą osobę dorastającego Zygmunta Luksemburczyka i zadanie rewindykacji Odolanowa [...] Jeśliby się uporał z krnąbrnym Bartoszem, zyskałby legitymację do rządzenia nie tylko w oczach przyszłego teścia, ale i przyszłych poddanych [...] Warto spojrzeć na posłanie margrabiego do Polski z tego punktu widzenia" (s. 130). Co więcej, autor uważa, że ruszający do Polski Zygmunt nawet nieszczególnie planował posługiwanie się tytułem wskazującym na przyszłe panowanie w Polsce. O umieszczeniu tego akcentu w dokumentach margrabiego zdecydowano dopiero po jego przybyciu do Polski w gronie polskich doradców i mentorów. Sugeruje to, że to sami Polacy nagle zaczęli go uważać za przyszłego króla, tytułując go dominus regni Poloniae. Badacz oparł się przy tym na tezie Zbigniewa Dalewskiego, że Zygmunt nie tylko występował jako uprawniony do dziedzictwa andegaweńskiego, ale raczej jako ktoś, kto zaczyna przejmować realnie władzę?. Tyle że Z. Dalewski napisał jeszcze, że takie działania Zygmunta były najpewniej wprost efektem zwoleńskiego hołdu, który uznał on za „pierwszy akt królewskiej inauguracji Zygmunta, wprowadzający go w prawa królów polskich"10. I chyba z tą konsta-

${ }^{8}$ Jan Zhořelecký třetí syn Karla IV. Edd. L. Bobková, T. Velička et al. Praha 2016, s. 44 .

9 Z. Dalewski: Władza, przestrzeń, ceremoniat. Miejsce uroczystości inauguracji władcy w Polsce średniowiecznej do końca XIV wieku. Warszawa 1996, s. 196.

${ }_{10}$ Tamże, s. 197. 
tacją należy się zgodzić. Przypisywanie polskim doradcom sprawczości w tej kwestii w ogóle nie przekonuje. Byłaby to niemal uzurpacja Ludwikowych prerogatyw, tym bardziej że w Polsce nie było już nawet kolegium wikariuszy, tak więc decyzja o tytulaturze Zygmunta byłaby decyzją bliżej nieokreślonego grona, którego składu można by się tylko domyślać. Z wywodu zaś D. Wróbla wynika, że hołd w Zwoleniu został złożony tylko dlatego, że chciał tego Ludwik, i nie bardzo wiadomo po co, ponieważ dopiero rozwiązanie kwestii Bartosza miało pokazać samemu królowi i Polakom, że Zygmunt nadaje się do rządzenia w Królestwie Polskim. Jest to koncepcja wynikająca wyłącznie ze spekulacji autora omawianej monografii, ponieważ oparta jest na zakwestionowaniu wartości przekazu jedynego źródła, które nam o zjeździe zwoleńskim i tym, co nastąpiło później, opowiada, czyli kroniki Jana z Czarnkowa. Tak więc skoro głównym zadaniem miało być pokonanie Wezenborga, to czemu Zygmunt pojechał w samym środku toczonych z nim bojów do Czech? Otóż D. Wróbel kwituje to stwierdzeniem, ,że młody Luksemburczyk nie podzielał opinii przyszłego teścia o pierwszorzędnej wadze likwidacji problemu Bartosza z Odolanowa. Niewykluczone jednak, że już wcześniej skontaktował się z Ludwikiem i uzyskał jego zgodę na wyjazd w rejon południowych Czech" (s. 146). Rodzi to zasadnicze trudności: po co w ogóle w takim razie Zygmunt wybrał się do Polski w sierpniu 1382 roku? Jest to bardzo wyraźny przykład sprzeczności i niekonsekwencji, które występują w wywodach D. Wróbla.

Konstruowanie przez autora wywodów pod z góry przyjętą tezę jest bardzo dobrze widoczne w obszernych rozważaniach o roli księcia mazowieckiego Siemowita IV. D. Wróbel odrzucił bowiem znaczącą rolę mazowieckiego Piasta w rywalizacji o polski tron w okresie między zgonem Ludwika a majem roku 1383 i uczynił z owego odrzucenia założenie, do którego dostosował pozostałe analizy. Przede wszystkim badacz podważył związki Bartosza Wezenborga $\mathrm{z}$ wielkopolskim rycerstwem, zwłaszcza z tzw. ziemianami, którzy na przełomie 1382/1383 czynnie wystąpili przeciw staroście wielkopolskiemu Domaratowi z Iwna. W kronice Jana z Czarnkowa jest wzmianka o tym, że ok. 20 grudnia 1382 roku Bartosz z mazowieckimi posiłkami starał się z zaskoczenia zająć zamek w Kaliszu, a po nieudanym ataku współdziałał z owymi ,ziemianami”. Kronikarz jednoznacznie napisał, że owi Mazowszanie towarzyszący Bartoszowi byli „gentibus ducis Masoviae”"11. Stąd D. Wróblowi pozostało jedynie izolować ekspedycję Bartosza, wskazując na brak jakichkolwiek związków między tym zdarzeniem a zbliżającym się zbrojnym wystąpieniem tzw. ziemian przeciw staroście wielkopolskiemu Domaratowi. Tymczasem przekaz Janka jest w tym względzie dość jednoznaczny i pokazuje, że celem ataku Bartosza i jego drużyny były miejsca kontrolowane przez załogi

${ }^{11}$ MPH, T. 2, s. $724-725$. 
starosty Domarata, przy co najmniej życzliwej neutralności „ziemian”, o czym właśnie świadczy ostatnie zdanie tego rozdziału, informujące o tym, że Wezenborg zaprzestał walk z Michałkiem z Ostrowieczna z chwilą, gdy ten prze-

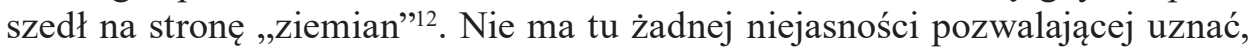
że Michałek, jak chce autor, dogadał się z wielkopolską szlachtą, żeby przypadkiem nie skapitulować wobec Bartosza. Konsekwentne dążenie D. Wróbla do wykazania braku związków między Wezenborgiem a wielkopolskim rycerstwem kłóci się chociażby z faktem wielkiej niemocy króla Ludwika i jego starostów, którzy bezskutecznie walczyli z dziedzicem Odolanowa. Dwukrotnie podjęte $\mathrm{w}$ tej kwestii wysiłki spełzły na niczym. Za pierwszym razem, jak wynika z relacji archidiakona gnieźnieńskiego, właśnie za sprawą postawy wysłanych przeciw niemu sił wielkopolskich, a potem w obliczu śmierci króla. Niechęć Wielkopolan do wojowania z Bartoszem jest bardzo dobrze widoczna. Narracja Jana z Czarnkowa wskazuje raczej w mojej opinii, że załamanie się działań Zygmunta Luksemburskiego jesienią 1382 roku i nierozstrzygnięcie kwestii następstwa tronu w Polsce na zjeździe w Wiślicy 6 grudnia stało się decydującym pretekstem, na który książę czekał lub który natchnął go myślą o polskim tronie. Ledwie dwa tygodnie po wiślickim colloquium oddział Bartosza stał u bram Kalisza. Z pewnością ma rację D. Wróbel, pisząc, że Siemowit działał ostrożnie i nie pojawił się sam, tylko wysłał do elit wielkopolskich - i zapewne też kujawskich — sygnał, że gotów jest być królem. To jednak tylko świadczy o tym, że myśl o królewskiej koronie nie zaświtała w jego głowie dopiero późną jesienią 1382, a tym bardziej dopiero w roku 1383. Mazowieckie posiłki wraz z Bartoszem nie opuściły przecież Wielkopolski po nieudanej próbie zajęcia Kalisza, tylko wraz z „ziemianami” podjęły walkę ze znienawidzonym starostą, ponieważ nie pojawiły się przecież w Wielkopolsce bez ich wiedzy ${ }^{13}$. Przekonuje o tym kolejny rozdział kroniki Jana z Czarnkowa, gdzie autor tłumaczy, dlaczego i z kim wojewoda poznański Wincenty z Kępy podjął walkę przeciw Domaratowi ${ }^{14}$. D. Wróbel zaś, aby wybrnąć z tej niespójności swoich wywodów, stara się dowieść, że między atakiem na Kalisz a styczniowym szturmem Pyzdr doszło do porozumienia między Wincentym a Bartoszem, które datuje na początek stycznia, podczas walk ze wspomnianym Michałkiem z Ostrowieczna (s. 247). Ponadto owo porozumienie miało nie zawierać wzmianki o osobie Siemowita jako potencjalnym kandydacie do tronu, ponieważ inaczej „ziemianie” zostaliby posądzeni o zdradę (s. 247-248). To z kolei zmusiło autora do snucia dalszych hipotez

12 Tamże.

13 Można się zastanowić, co zrobiłby Bartosz, gdyby udało mu się jednak zająć Kalisz w ramach wyprawy niezależnej od zamiarów Wincentego z Kępy. Ogłosiłby, że zamek i miasto są w rękach nowego kandydata do tronu Siemowita IV? Autor napisał, że akcja Bartosza to był gest wsparcia, życzliwie przyjęty przez Wielkopolan (por. s. 247).

14 MPH, T. 2, s. $725-726$. 
o tym, że Bartosz, wkraczając do Wielkopolski, nie ujawniał planów Siemowita, ale działał na terenie bezpośrednio graniczącym z jego własnymi utraconymi we wrześniu majątkami i — jednym słowem - ukrywał prawdziwe intencje. Tym samym porozumienie między Wezenborgiem a „ziemianami” miało mieć dla tych drugich charakter czysto taktyczny (s. 248). Znacznie prościej wygląda w moim przekonaniu wyjaśnienie oparte nie na spekulacjach, ale na źródle, które może nie dosłownie, ale sugestywnie podpowiada rozwiązanie. Jest nim oczywiście kronika Jana z Czarnkowa. Opisując zjazd rycerstwa z posłami węgierskimi w Wiślicy w dniu 6 grudnia 1382 roku, kronikarz napisał, że królowa Elżbieta Bośniaczka prosiła Polaków o wierność tylko córkom Ludwika i nieskładanie hołdu nawet Zygmuntowi ${ }^{15}$. Tym samym kwestia przyszłego króla-małżonka nie została przesądzona. W każdym razie dla Polaków bo czy Elżbieta kalkulowała, że uda się jeszcze przekonać bądź przymusić polskich poddanych do pozostania w unii personalnej (do czego się skłaniam), nie wiadomo. Natomiast nie można w związku z tym wykluczyć pojawienia się pomysłu Siemowita jako potencjalnego małżonka którejś z królewien. Taką koncepcję mógł śmiało wówczas podnieść sam książę mazowiecki i zacząć przekonywać do niej Wielkopolan, najbardziej zaangażowanych w domaganie się stałej rezydencji monarchy w kraju. W takim ujęciu interpretacja sekwencji zdarzeń z przełomu 1382 i 1383 roku nie wymaga budowania nadmiernie rozdętych hipotez.

Swego rodzaju kulminacją analiz, prowadzonych na podstawie niezachwianego przekonania autora, że Siemowit IV nie był w tym czasie poważnie zaangażowany w rywalizację o polski tron, jest podrozdział Rozejm starczynowsko-radzimski (8 marca 1383 r.) (s. 288-301). Jest to interpretacja wydarzeń, które rozegrały się zaraz po pierwszym zjeździe sieradzkim, kiedy to królewna Jadwiga przedstawiona została Polakom jako nowa dziedziczka polskiej korony. Po zakończeniu spotkania doszło do próby załagodzenia konfliktu w Wielkopolsce, czyli wojny między ,ziemianami” i starostą Domaratem. Wszystko zostało bardzo czytelnie opisane przez Jana z Czarnkowa. D. Wróbel jednak rozpoczął swoje wywody od stwierdzenia, że opis wydarzeń kalisko-starczynowskich, jaki dał kronikarz, ,jest miejscami niezbyt jasny" (s. 288). Mam nieodparte wrażenie, że zabieg taki był badaczowi potrzebny, aby móc utrzymać swoją interpretację politycznych zawirowań, opartą na pomniejszaniu znaczenia Siemowita IV jako poważnego kandydata do korony. Jan z Czarnkowa napisał, że po zjeździe w Sieradzu wojewoda Spytek z Melsztyna i Sędziwój z Szubina wraz z towarzyszącymi im rycerzami udali się do Kalisza z dokumentami królowej. Porozumieli się wówczas z załogą wierną staroście Domaratowi, że odda im zamek, który przejmą w imieniu królowej Elżbiety Bośniaczki. Podobnie zamierzali zrobić z pozostałymi za-

15 Tamże, s. 724. 
mkami i miastami królewskimi w Wielkopolsce ${ }^{16}$. D. Wróbel znalazł w tym fragmencie szereg koniecznych do wyjaśnienia wątpliwości, co poskutkowało propozycją całkowicie hipotetycznych tez, które stały się podstawą dalszego wnioskowania. Pierwszym jego krokiem było zasugerowanie, że wspomniane przez kronikarza listy królowej Elżbiety, które wojewodowie przywieźli do Kalisza, nie miały jasnego związku z planami zakończenia konfliktu: „Nie wiadomo jaka była treść owych dokumentów (listów, mandatów?). Z faktu, że mieli je ze sobą delegaci zjazdu sieradzkiego [...] należy wnosić, że dotyczyły one konfliktu wielkopolskiego" (s. 290-291). Tymi uwagami autor dokonał dwóch rzeczy: po pierwsze, zasiał wątpliwość, czy królowa Elżbieta Bośniaczka szczególnie interesowała się sprawą nabrzmiałego konfliktu. A po drugie, co wydaje się ważniejsze, nazwał przybyłych do Kalisza wojewodów delegatami zjazdu sieradzkiego. A to z kolei powoduje, że plan rozwiązania konfliktu w Wielkopolsce był inicjatywą rycerstwa zgromadzonego w Sieradzu, które owych delegatów, jak rozumiem, wysłało do Kalisza. Nic takiego nie wynika z przekazu Jana z Czarnkowa, który napisał: „De conventioni autem Syradiensi [...] in dominica Laetare venientes Spitko Cracoviensis, Sandivogius Kalisiensis palatini [...] in Kalis cum litteris regine praedictae"17. Kronikarz wyraził się według mnie wystarczająco jasno i nie ma tu szczególnych wątpliwości, iż obaj wojewodowie i towarzyszący im rycerze udali się, aby zrealizować plan bez wątpienia uzgodniony z królową, czego dowodem były opieczętowane przez nią dokumenty, w treści których zapewne znajdowały się postanowienia odnośnie do mającego nastąpić porozumienia, opisanego przez Jana z Czarnkowa w następnym zdaniu. Dariusz Wróbel jednak brnie dalej w spekulacje, wskazując, że nie wiadomo, czy przybyli do Kalisza negocjowali „w jednostkowej sprawie tamtejszego zamku", czy też działali w celu rozwiązania konfliktu w skali całej Wielkopolski. Tymczasem opis archidiakona nie budzi żadnej wątpliwości, że w grę wchodziła druga opcja. Sugerowanie, że królowa przysłała do Polski listy w celu załatwienia sporu o kontrolę nad jednym zamkiem w Kaliszu, a realizujący to zadanie możni zamierzali to rozstrzygnięcie ,skopiować w odniesieniu do pozostałych obiektów w Wielkopolsce (zamków i miast)" (s. 292), brzmi co najmniej przedziwnie. Autor zupełnie nie dostrzega, że narracja kronikarza jest bardzo precyzyjna, albowiem kiedy negocjacje w Kaliszu spełzły na niczym i nie udało się zrealizować porozumienia w zaplanowanym kształcie, to obaj wojewodowie natychmiast opuścili Polskę, udając się pospiesznie na Węgry ${ }^{18}$. Przekazanie zamku kasztelanowi kaliskiemu Janowi z Jankowa nie było w żadnym razie satysfakcjonujące dla Spytka i Sędziwoja, a przede wszystkim opór, jaki stawili im Wielkopolanie, nie godząc się na oddanie zamków oraz miast ziem kaliskiej i poznańskiej pod zarząd ludzi mających

\footnotetext{
16 Tamże, s. 733-734.

17 Tamże, s. 733.

18 Tamże.
} 
je objąć w imieniu królowej, podobnie (similiter) jak to miało mieć miejsce w Kaliszu, zniweczył cały plan ${ }^{19}$. Wszystkie pozostałe sprawy, a więc, wydawałoby się, arcyważny rozejm między „,ziemianami” a Domaratem z Iwna, pozostawili w rękach mniej znaczących dostojników: kasztelana zawichojskiego Mikołaja Bogorii i rycerza Krzesława. Dariusz Wróbel zaś pisze tak: „Ostatnio Andrzej Marzec połączył nagły wyjazd wojewodów ze wzmianką w dziele archidiakona gnieźnieńskiego o nieporozumieniach jakie zaszły w Kaliszu. Ten pogląd wynika z przekonania historyka, że posłowie węgierscy »przybyli z precyzyjnie nakreślonym planem całościowego rozstrzygnięcia spraw polskich, który został przedyskutowany z przebywającymi na Węgrzech polskimi posłami«. Mamy więc do czynienia z powrotem koncepcji Józefa Szujskiego o uzgadnianiu polityki królowej matki z panami małopolskimi ponad głowami "pospólstwa« całej Korony" (s. 294-295). Mocno nieprzekonująca jest taka opinia, tym bardziej że niczego nie musiałem łączyć, ponieważ jak pokazuje umieszczony w przypisie cytat, informacja o wyjeździe dostojników jest integralną częścią całej opowieści archidiakona gnieźnieńskiego o wydarzeniach w Kaliszu ${ }^{20}$. Janko napisał, co przecież nie powinno wymagać jakiegokolwiek tłumaczenia, że „ziemianie” nie zgodzili się na zamiary wojewodów i po wynikłych $\mathrm{z}$ tego napięciach zawarto jakieś porozumienie, a „Palatini vero praedicti versus Ungariam [...] festine [podkr. - A.M.] processerunt”. Klarowność opowieści kronikarza jest uderzająca. Dla lubelskiego badacza sprawa jednak nie jest jasna, albowiem ,z przekazu Jana z Czarnkowa wynika, że delegaci królowej Elżbiety i zjazdu sieradzkiego przedstawili w Kaliszu propozycję [...], która polegała na pozbawieniu obu stron oparcia w punktach umocnionych, używanych jako bazy wypadowe, miejsca gromadzenia łupów oraz

19 Tamże: „Et tandem post aliquam dissensionem hinc inde habitam, utraque pars 'compromisit' Joanni Kalisiensi castellano castrum Kalisiense et civitatem et terram gubernandam committentes. Palatini vero praedicti versus Ungariam ad reginam festine processerunt".

${ }^{20}$ Nagła podróż wojewodów z Kalisza na Węgry miała być według D. Wróbla wynikiem niepokojów na Kujawach. Autor odwołuje się do fragmentu kroniki Jana z Czarnkowa, który opisując zajęcie Kujaw przez księcia Siemowita na przełomie maja i czerwca 1383 r., wspomniał, że już w czasie Wielkiego Postu tego roku doszło do konfliktu między szlachtą a starostą kujawskim Piotrem Małochą, który zdradził na rzecz księcia mazowieckiego (tamże, s. 739: „Nam in Quadragesima precedenti”). D. Wróbel chętnie datuje więc to zdarzenie na początek marca 1383 r., tak, aby był to pretekst do wyjazdu wojewodów na Węgry. Tylko tym samym zastawia pułapkę na samego siebie. Skoro bowiem w początkach marca na Kujawach dochodzi do walki szlachty ze starostą, który opowiada się za księciem mazowieckim, to jakim sposobem ten problem nie stał się przedmiotem uwagi szlachty wielkopolskiej, a przede wszystkim — jak można jeszcze mówić, że pretensje Siemowita IV nie były istotnym problemem? Ale dla autora „w ówczesnym dyskursie publicznym kandydatura mazowiecka do tronu wciąż jeszcze nie istniała, niezależnie od tego, czy wśród możnych koronnych, zwłaszcza małopolskich, już zdawano sobie sprawę z ambicji dworu płockiego czy nie" (s. 296-297). 
oczywiście miejsca doraźnego schronienia przed przeciwnikiem” (s. 295) ${ }^{21}$. Po czym w następnym zdaniu D. Wróbel sam stwierdza, że taki pomysł nie mógł być skuteczny, ponieważ oprócz miast i zamków królewskich istniały zamki, dwory, wsie i miasta prywatne. Wynika więc z tego, że te ,punkty umocnione", które mieli zając wojewodowie i ich ludzie, to jednak miasta oraz zamki królewskie - i to o nie toczyła się gra. Zresztą w tym samym rozdziale, czego autor nie widzi, Jan z Czarnkowa napisał, że zawarty w Starczynowie rozejm z Domaratem pozostawił w jego rękach zamek w Poznaniu ,et caetera castra regalia ac oppida et municipia"22. Wszystkie te zawiłe spekulacje badacza są podyktowane koniecznością ratowania tezy o co najmniej marginalnym znaczeniu osoby Siemowita IV w pierwszym okresie bezkrólewia — zarówno na lokalnym szczeblu wielkopolskim, jak i na szczeblu ogólnopolskim oraz w polityce dworu budzińskiego ${ }^{23}$.

Przedstawione przykłady w mojej opinii dobrze ilustrują kontrowersyjną metodę analizy źródeł i interpretacji przekazów odnoszących się do opisywanych przez D. Wróbla czasów. Przyjmowanie tezy, której podporządkowane zostają wszystkie pozostałe analizy, musi prowadzić do pojawienia się sprzeczności, nielogiczności i nierozwiązywalnych problemów. W efekcie powstają zupełnie nieprzekonujące wnioski i interpretacje. Nie da się w krótkim tekście odnieść do większości kontrowersyjnych wywodów badacza, jak i przekonująco pokazać słabości jego konkluzji, które wynikają z dłuższych i skomplikowanych analiz. Zaprezentowane przykłady miały jedynie zilustrować nietrafność zastosowanej metody, czyli prób naginania źródeł w celu utrzymania przyjętego z góry założenia. Szerszą dyskusję z niektórymi tezami autora podejmę w innym miejscu ${ }^{24}$.

4. Tytuł recenzowanej książki pozwala czytelnikowi oczekiwać, że znajdzie rozdział bądź rozdziały, w których zostaną omówione takie zagadnienia, jak: kondycja stanu szlacheckiego w ostatnich dziesięcioleciach wieku

${ }^{21}$ Tak należy, jak mniemam, rozumieć według autora zdanie: „Similiter de omnibus castris et civitatibus Poloniae praefati palatini et eorum consortes se intromittere volebant" MPH, T. 2, s. 733.

22 Tamże, s. 734.

${ }^{23}$ Odrzucił więc także moją sugestię (A. Marzec: Pod rządami nieobecnego monarchy. Królestwo Polskie 1370-1382. Kraków 2017, s. 221), że celem królowej Elżbiety wysyłającej do Polski Sędziwoja z dokumentami było uspokojenie sytuacji w Wielkopolsce — przede wszystkim po to, aby zabezpieczyć się przed niebezpieczeństwem grożącym ze strony księcia mazowieckiego. Zdobycie strategicznej przewagi nad tym Piastem przez zabezpieczenie królewskich miast i zamków w Wielkopolsce jest jak najbardziej racjonalnym działaniem wobec toczącej się tam wojny domowej i chęci opóźnienia przybycia królewny Jadwigi. Szala poparcia dla Siemowita mogła w każdej chwili przeważyć i naprawdę zagrozić stabilności władzy andegaweńskiej, skłócony zaś ze szlachtą starosta nie mógłby temu przeciwdziałać.

${ }^{24}$ Będzie to drugie, uzupełnione wydanie książki Pod rządami nieobecnego monarchy. Królestwo Polskie 1370-1382. 
XIV, obraz elity politycznej, jej wewnętrznego zróżnicowania, ewentualnych podziałów, czy wreszcie ustrój królestwa. Autor odmienia na różne sposoby pojęcia takie jak np.: „stan szlachecki”, „,rycerstwo”, „elita”, „,naród polityczny”, „wspólnoty ziemskie”, „panowie krakowscy”, „Corona Regni Poloniae”, „roszczenia terytorialne szlachty”, „wspólnota państwowa”. Niestety nie ma w książce akapitów, które pozwoliłyby czytelnikowi dowiedzieć się, jak rozumie te terminy. Dla D. Wróbla są one zapewne oczywiste. Widać to przy omawianiu problemu Rusi Halicko-Włodzimierskiej, gdzie autor przyjął bezdyskusyjnie istnienie powszechnego przekonania polskiego rycerstwa, że Ruś jest integralną częścią Królestwa Polskiego. Skutkuje to budowaniem dość karkołomnych tez, dotyczących tego, że polskie i węgierskie elity traktowały ziemie ruskie jako część jednego bądź drugiego królestwa, Ludwik zaś uważać miał Ruś za część swej dynastycznej domeny, niezależną od korony węgierskiej czy też polskiej. W efekcie kwestia ruska miała być jednym z kluczowych problemów relacji i dyskursu polsko-węgierskiego w czasie panowania Ludwika i po jego śmierci (s. 93-94, 317-319). Niestety na tym sprawa się kończy. Nie zostało to w żaden sposób uzasadnione. Warto przypomnieć, że polityczny dyskurs w relacjach polsko-węgierskich miał stanowić jeden z głównych wątków omawianej książki. Brak głębszego przemyślenia spraw ustrojowych widoczny jest także w niejasnym podejściu do tzw. panów krakowskich — raz uważanych za centralne postaci życia politycznego (misja Sędziwoja do Marchii Brandenburskiej jesienią 1381 roku — s. 128), innym razem nie (okoliczności powołania kolegium wikariuszy królestwa w początkach roku 1381 s. 110). Wreszcie pojawiają się sugestie co do istnienia jakiegoś ogólnopolskiego forum opinii rycerskiej, a może międzystanowej, którego zdanie mogło ważyć na decyzjach elitarnych kręgów, bądź forum to miało jakieś możliwości rozliczania węższych kręgów dostojniczych z podejmowanych przez nie decyzji. Tak np. opisuje D. Wróbel powody zawarcia porozumienia z królową Elżbietą Bośniaczką w Koszycach wczesnym latem 1383 roku: „Tymczasem w wyznaczonym terminie królowa matka i jej młodsza córka nie pojawiły się w Polsce. [...] Zgodnie $z$ duchem niedawno powziętych uchwał powinni [możni polscy - A.M.] teraz wycofać się z Sącza i podjąć kroki w sprawie wyboru nowego króla. To jednak oznaczałoby przyznanie się do porażki politycznej i mogłoby zachwiać ich dotychczasową dominacją. Stanęli przed koniecznością ratowania własnej reputacji i autorytetu, nie mogli przecież wrócić do Krakowa z pustymi rękami" (s. 335). Wywód ten sugeruje, że w Krakowie czekała dostojników konieczność wytłumaczenia się przed... no właśnie — przed kim? To pokazuje, że brak pogłębionych analiz realiów ustrojowo-społecznych ówczesnego Królestwa Polskiego pozostawia przedstawione stwierdzenia w próżni, a można było te kwestie przecież z powodzeniem pogłębić. Podsumowując swoje obszerne rozważania na temat wydarzeń z 1 . poł. roku 1383, autor napisał, że ,program terytorialnych rewindykacji należał do stałego katalogu postu- 
latów szlachty". To bardzo ogólne sformułowanie, przewijające się na kartach książki, aż prosi się o jakiś komentarz. W następnym zaś zdaniu czytamy: „Czas bezkrólewia sprzyjał tego rodzaju inicjatywom [rewindykacji terytorialnych - A.M.], które dopełniały ówczesny program polityczny możnych i szlachty polskiej i zarazem dodawały mu waloru strategicznego. Wspólnota państwowa występowała w rolach strażników i rzeczników całości i niepodzielności Korony Królestwa" (s. 351). Gdzie indziej D. Wróbel charakteryzuje oczekiwania szlachty wobec ciągle nieobecnego króla, pisząc: „Monarcha rezydujący w kraju miał być symbolem nowego otwarcia po dwunastoleciu rządów nieobecnego króla. Miał wprowadzić Królestwo z powrotem na drogę, którą kroczyło w czasach Kazimierza Wielkiego, a z której zboczył jego następca" (s. 300). Brzmi to znakomicie, ale niczego w gruncie rzeczy nie wyjaśnia, ponieważ użyte pojęcia nie odsyłają do jakiejkolwiek propozycji kształtu ustroju i społeczeństwa ówczesnej Polski. Podobnych miejsc w książce jest wiele.

Ujęte na ośmiu ostatnich stronach książki Refleksje końcowe nie są w stanie zastąpić dogłębniejszych analiz sygnalizowanych zjawisk. Autor nie wyszedł poza dość ogólne konstatacje. Poskutkowało to powtarzaniem schematycznych sformułowań: ,[...] bezkrólewie po Ludwiku stanowi okres szczególny ze względu na usytuowanie zbiorowego czynnika społecznego na centralnej pozycji, na owym pierwszym planie, który widnieje w tytule pracy”. Kawałek dalej: „Rys niezależności i podmiotowości czynnika społecznego — możnych i reprezentowanej przez nich szlachty — jest widoczny zarówno w fazie formułowania celów i inicjowania działań, jak i w fazie ich realizacji” (s. 495). W innym miejscu: „Możliwe że Kujawianie z brzeskiej wspólnoty terytorialnej początkowo poparli Zygmunta Luksemburskiego i dlatego nie wzięli udziału w konfederacji radomszczańskiej” (s. 500). Czym była „brzeska wspólnota terytorialna", jak należy ją sytuować wobec innych wspólnot, jakich? Jak w ogóle wyglądała kwestia tożsamości wspólnotowej szlachty tego czasu? Brak analiz sygnalizowanych zjawisk ustrojowych i społecznych widać też mocno w tych częściach książki, a jest ich sporo, gdzie przedmiotem uwag autora są liczne zjazdy szlachty i możnych. D. Wróbel doskonale zdaje sobie sprawę z wagi tych spotkań, ale nie poddaje ich osobnej refleksji. Widać to wyraźnie przy szczegółowym opisie drugiego zjazdu radomszczańskiego. $\mathrm{Z}$ opisu postanowień tego spotkania nie wynikają żadne szersze konkluzje odnoszące się do dynamicznej ewolucji mechanizmów zarządu terytorialnego w królestwie i znaczącego osłabienia autorytetu urzędów starościńskich. Szkoda, że w książce nie znalazł się rozdział, w którym wszystkie te sprawy zostałyby poddane osobnym przemyśleniom, wyabstrahowanym z gąszczu faktograficznych ustaleń autora, a umieszczonym na tle przemian ustrojowo-społecznych czternastowiecznej Polski.

5. Książka Dariusza Wróbla bez wątpienia będzie jeszcze przedmiotem wielu uwag i dyskusji. Jej podstawową zaletą jest zupełnie nowe opisanie cza- 
sów bezkrólewia. I choć, jak starałem się wykazać wcześniej, z wieloma zaproponowanymi przez autora wnioskami i interpretacjami się nie zgadzam, to zarysowanie nowego obrazu tych odległych zdarzeń z pewnością sprzyjać będzie dalszym badaniom i dyskusjom. Najbardziej należy żałować, że badacz, poświęcając niemal całą energię na zbudowanie nowej faktografii czasów bezkrólewia, nie podjął głębszych analiz społeczeństwa rycerskiego i przemian ustroju Królestwa Polskiego, a po tytule i wyłożonych we wstępie deklaracjach można się było spodziewać obszerniejszego uwzględnienia tych wątków. 